the good it would do to allow women to preach, which requires Latin scripture and religious texts to be translated into the vernacular; these arguments attracted a lot of attention, including in places proximate to Chaucer; and Chaucer's Second Nun and Prioress in their prologues and tales make conspicuous gestures at these arguments and the controversies they generated. Her second task begins with her second chapter and the female religious communities at Amesbury and especially Syon, institutions well primed for engaging the issues Warren has identified. She considers how "Chaucerian texts ... provided means of self-fashioning and identity formation" for these women "as they negotiated fraught periods of political and religious turmoil, especially in the first half of the sixteenth century" (48). One of her striking arguments here: the women of these communities resemble the Second Nun and the Saint Cecilia of her tale in both personal background and collective political activity on behalf of their community's interests.

Her third chapter explores both how Chaucer shows up quite prominently in "allusions and references and, even more importantly, the adoption of Chaucerian narrative strategies and personae" in Thomas More's Dialogue Concerning Heresies (71), and how he figures in William Forrest's writings, especially his History of Grisild the Second (1558). In Chapter 4 she discusses how Dryden "found" Chaucer useful to "reanimat[ing] England as a Catholic realm and Roman Catholic devotion as the authentically English faith" (98). Her final chapter looks at two references by Mather in Magnalia Christi Americana to "old Chaucer" that place the fourteenth-century poet "at the head of a chain of the sacred, reformed dead," including "John Leaf, John Bradford, and William Bradford" (143).

Warren thankfully treads carefully throughout, fully aware that she is more often smelling smoke than locating actual fires. I have quibbles with her reading of More and with her use of "Chaucer of the Retraction" as the shorthand for early modern re-Catholicized Chaucer. But I think her work is illuminating and lays good groundwork for further scholarship in the different corners of the field she explores.

Joseph Parry, Brigham Young University doi:10.1017/rqx.2020.396

\title{
The Long Public Life of a Short Private Poem: Reading and Remembering Thomas Wyatt. Peter Murphy. \\ Square One. Stanford, CA: Stanford University Press, 2019. xx + 248 pp. \$28.
}

For a poet associated with lyric brevity, one whose poetry compresses paradox and intrigue into tightly bound forms, this extensive four-part study devoted to a single, short Wyatt poem - "They Flee from Me" (three stanzas, barely fifty words each) would seem to be a wanton, disproportionate splurge. Yet Murphy's book amply 
justifies its length, coupling a thorough reconstruction of the poem's longue durée with a briskness and fizz that propel its critical narrative along. Tracing the poem's evolution from first principles (consonant with the series title, Square One) and for a general, intellectually curious readership, this study meticulously maps the eddies and currents that have defined this vexing poem's vexed history of neglect, rediscovery, and canonization, which Murphy persuasively frames as a process of maturation. Rather than a static bequest to literary history, this poem, by virtue of its enduring capacity to surprise and perplex (who or what, in a "centuries-long scholarly puzzling," is "stalking" [139]?), evolves over time, in an ongoing tussle with both time and the forces of cultural entropy, obsolescence, and oblivion.

The book reconstructs the poem's composition and reception history in four parts, a history of vacillating attitudes about its value and about literary value itself. Is this poem "exceptional" (208)? Are its irregularities "a sign of genius or incompetence" (212)? Part 1 singles out the poem in Wyatt's personal Egerton Manuscript as "a virtuoso performance" (20) composed within and against the conventions of rhyme royal poetry of love and regret, before Murphy traces the poem's transmission through variant versions in manuscript and print (notably Tottel's Miscellany). Part 2 assesses how the poem was handled by eighteenth-century editors (often wrangling with each other) in a narrative of crucial but chance interventions, from Edmund Curll's reprinting of the poem in "Antique Dress" (82) to Thomas Percy's annotations-an "antientropic Event" (90)—which bestowed an aggrandizing "Classic Elegance" (106) on it, to Henry Harington's "accidental" (109) browsing in a library that helped inscribe Wyatt's poem within "a conceptual structure . . literature" (110). Citing commercial motives for the perpetuation of Tottel's version (not Wyatt's original) in print anthologies, Murphy surveys the poem's afterlife over the nineteenth and early twentieth centuries in part 3, dwelling on the staggering, singlehanded erudition of G. F. Nott-instrumental in recovering the "messy primal energy" (134) of the original manuscript, as was, a century later, Agnes Foxwell, the "first woman to record her thinking about our poem since the 1530s" (154). From these first signs of institutionalized critical attention and the emergence in classrooms of a "professorial 'They Flee from Me" (156), part 4 charts the poem's twentieth-century afterlife in American universities, spurred by New Critics' enchantment with the poem (Brooks, Warren) and sustained by later critical responses (Stein, Greenblatt).

Part close reading of the poem's riddling, "unfinished quality" that withholds explanation (62); part book history of the text's material incarnations throughout its "object-life" (3), including an anonymous thumb-print smudge left in a Tudor manuscript copy; and part critical heritage assessing the competing ideological appeals of historicism and presentism, Murphy's study combines scholarly attentiveness with a wry air of amused curiosity-hence such subheadings as "(Vegetarians)" (118) or "Moving On, Sort Of” (203). Grippingly unusual, this book conveys something of the Egerton Manuscript's layered hybridity: an amalgam of text and image, peppered 
with fragmentary, gnomic headings and samples of unnamed handwriting. Among Murphy's strengths is his attentiveness to the poem's materiality-its chance survival ("Thancked be fortune") through layers of accretions (Cossicke algebra, moral maxims, diary entries, children's doodles) and its endurance as much because, as in spite, of the genealogy of corruptions and errors that have dogged its reproduction and curation: "thinne" becomes "thine" (86); "me" becomes "we" (88); "she" is added (143); "heart" dropped (180). The poem's history, Murphy deftly shows, is of a private poem becoming a public commodity, and of what is vibrant being deadened and frozen by the very mechanisms seeking to preserve texts. This poem of remembering and forgetting, of intense immediacy and loss, of the simultaneous appeal and threat of "newfangleness," is itself, as it transmigrates through different kinds of objecthood, the product of remembering, forgetting, and re-remembering. This study will play no small role in ensuring its continued remembrance.

Chris Stamatakis, University College London doi: $10.1017 /$ rqx.2020.397

The Cambridge Companion to Shakespeare's Language. Lynne Magnusson and David Schalkwyk, eds.

Cambridge Companions to Literature. Cambridge: Cambridge University Press, 2019. xiv +298 pp. $\$ 24.99$.

"There has never been a more exciting time to be working on Shakespeare's language," writes Jonathan Hope in one of the fifteen essays collected in Lynne Magnusson and David Schalkwyk's edition of The Cambridge Companion to Shakespeare's Language. Although modern crib notes often represent Shakespeare's language as an obstacle to enjoying his works, the first half of this collection provides several accessible entry points toward understanding how early modern English evolved in the context of classical pedagogies and rhetoric, in conversation with European and native versification, and in social contexts. The latter half invites users to explore how Shakespeare's language works using digital tools, and to consider performance in both translation and today's popular culture. Access to newly digitized knowledge bases not only enlivens the "New Technologies" section, but also vivifies contributions throughout this fine collection of rigorously researched and eminently teachable essays.

A consistently strong cohort of contributions by Jeff Dolven, Alysia Kolentsis, David Schalkwyk, Oliver Morgan, Lynne Magnusson, and Ruth Morse comprise part 1, entitled "Basic Elements." Dolven's introduction to Ciceronian hierarchies of style and his demonstration of how they figure in Shakespeare's early, middle, and later plays is both thorough and engaging. Kolentsis follows with an exploration of Shakespeare's lexical elasticity in the context of conventional grammar school instruction; this essay pairs well 